\title{
Internet usage and self-regulated learning assessment at junior high school students in Tasikmalaya City, Indonesia
}

\author{
R. Reza El Akbar*1, Nani Ratnaningsih ${ }^{2}$ and Edi Hidayat ${ }^{3}$ \\ ${ }^{1}$ Department Informatics Engineering, Siliwangi University, Indonesia \\ ${ }^{2,3}$ Department Mathematics Education, Siliwangi University, Indonesia \\ J1. Siliwangi No. 24 Tasikmalaya 46115, Indonesia, Telp. (0265) 330634 Fax. (0265) 325812 \\ *Corresponding author, e-mail: reza@unsil.ac.id
}

\begin{abstract}
Internet use for junior high schools in Tasikmalaya city, dominated for game play and social media. This research describes the pattern of relationship between internet usages on students, on the assessment of aspects of selfregulated learning. The aspect of self-regulated learning measured from 10 aspects. This study discusses the effects of gender, the categories of schools (excellent schools and regular school), the total value of self-regulated learning and the value of math exams. In brief, the research stages consist of three stages. The first stage of research is to create and retrieve the questionnaire data. The goal is to obtain all things related to internet usage, as well as measure aspects of self-regulated learning assessment. The second stage of treatment on students. This treatment time is done for four months, where students follow the math lesson with self-regulated learning method. Students provided with multimedia devices, textbooks and other. The third stage is the assessment or math test. The analytical method used is qualitative method with descriptive statistical approach. The results obtained that the dominant male students using internet for games tend to have greater Aspects of Finding and Utilizing Relevant Learning Resources. While female, tend to be dominant in aspects of Evaluating Learning Processes and Results. The average mathematical exam results, in students who often use the game tend to have a higher value, compared with other students who often use social media.
\end{abstract}

Keywords: internet usage, self-regulated learning, social media and game.

Copyright $\left({ }_{0} 2019\right.$ APTIKOM - All rights reserved.

\section{Introduction}

Tasikmalaya is a city located in the western Java region, is about $260 \mathrm{KM}$ from the city of Jakarta, the capital of Indonesia. The use of internet connection in this city from year to year continues to increase. Tasikmalaya has the nickname "Kota Santri", because the city has many Muslim boarding schools (Pesantren). Students living in Muslim boarding schools called "santri and santriwati". Policies related to the use of internet connection in some pesantren is to prohibit students to use mobile devices, tablets or other electronic devices connected to the internet, as well as some elementary schools in this city.

In junior high school, which is a continuation of primary school, internet use may be used in school environments, but limited by its usage rules. The categories of schools in Tasikmalaya city can be divided into two categories: excellent schools and regular school. The excellent schools is filled with outstanding students at elementary school. While for regular school is a school whose students have an average grade in their primary school. Excellent and regular schools can come from schools based on boarding schools or non-pesantren schools.

Associated with internet usage, several studies have been conducted. One of them is research that examines the influence of internet and its usage [1]. In the study explain the use of internet, including the use of the internet to play games that amounted to $26.3 \%$ of the sample research studied. In 2016 as reported by the bulletin of the association of internet service providers Indonesia [2] the largest use of internet used for social media and entertainment. In line with these studies, preliminary survey results from this study conducted in 2017 obtained internet use among junior high school in tasikmalaya environment has two major rankings, internet usage is for social media and game play, while the rest use both or other. Internet usage such as social media and games has an impact on individual changes. Changing the way individuals interact with others is one of its effects [3]. As for the influence of internet usage, specifically to the assessment of aspects of self-regulated learning. This influence has not specifically found. So, based on the description of this research describes the use of the internet, especially for playing games and social media. The object of this research is junior high school students. The use of the internet studied in more detail to 
the assessment of aspects of self-regulated learning. It becomes interesting to investigate, because playing games and social media suspected to have an interesting positive impact.

Self-Regulated Learning is a process of self-monitoring design and careful review of the cognitive and affective processes in completing an academic task [4]. Assessment of the aspects of Self-regulation learning consists of several parts including Rehearsing and memorizing, goal setting and planning and others [5]. Perform an independent self-assessment assessment by using a questionnaire [6] or interview [6]. In this study, questionnaires chosen to be use, as the number of respondents was overwhelming. The aspects of self-learning used to assess aspects of self-learning [7, 8]. Aspects of independent learning are (1). Learning Initiative; (2). Diagnosing the Needs of Learning; (3). Setting Learning Objectives; (4). Organize and Control Performance / Learning; (5). Organize and Control Cognition, Motivation, Behavior (Self); (6) Viewing Difficulties as a Challenge; (7). Finding and Utilizing Relevant Learning Resources; (8) Choosing and Applying Learning Strategies; (9). Evaluating Learning Processes and Results, (10). Selfefficacy (Self Concept).

Kencho Tshering [4] has studied other studies related to the use of the Internet by comparing gender. The title of this study is to Study the Internet Access and Usage Behavior in the Kingdom of Bhutan. The results show there is no difference in the actual of the Internet between male and female. In this research, a study of differences across gender, along with the characteristics of excellent schools and regular school, on the use of the internet to play games, social media or both.

Based on the background description, this research will generally explain the influence of internet usage on the assessment of self-regulated learning aspects for junior high school students in Tasikmalaya City, Indonesia. Comparisons between gender and classification of school categories (excellent schools and regular school), are part of this study. Internet use in this study focused on the use of the internet to play games, social media or both. Specifically this study has three main objectives. The first objective is to know the pattern of relationships between internet use (playing games, social media, or both) on male and female students for schools with excellent schools and regular school categories. Second Objective identifies aspects of self-regulated learning in male and female students for schools of excellent schools and regular school. The third goal to know the order of priority of each aspect of the formation of self-regulated learning, in terms of the average pattern of each aspect obtained. The fourth objective is to obtain a mapping of the relationship between gender, school characteristics, internet used and mathematics test scores.

\section{Research Method}

\subsection{Determination of Research Design and Respondents}

At this stage is planned and designed research, including variables to be researched and technical implementation of research. At this stage also determined the study respondents.

\subsection{Designing and Creating Questionnaires}

The questionnaire consisted of three parts. the first part contains the respondent's biodata, the second part about internet usage, the third contains the self-regulated learning questionnaire. Questionnaires were distributed after a preliminary trial of the questionnaire was made.

\subsection{Secondary data retrieval}

Secondary data is taken from the results of student ratings after attending self-regulated learning for mathematics lessons. The result of the students' learning scores is obtained from the math test score at the end of treatment.

\subsection{Processing and Analysis of Research Data}

The first data processing is done by converting the self-regulated learning question items from the questionnaire statement into the percentage form. Data analysis used in this research use qualitative analysis by using descriptive statistic approach. This study uses qualitative data analysis with descriptive statistical approach by looking at the average distribution of each fariabel studied

\section{Results and Analysis}

\subsection{Determination of Research Design and Respondents}

The study was conducted on students in two different junior high schools in Tasikmalaya city, with Excellent and regular schools categories. Variable internet usage used in this research is internet usage

APTIKOM J. CSIT Vol. 4, No. 2, 2019: 69-73 
to play game online and social media. Other variables studied were gender influences, school category, mathematics test scores and values from respective aspects of the self-regulated learning.

After initial coordination is done with both schools. Students are first given a questionnaire to collect demographic data information, a tendency to use the internet (play game, social media or both) and assess the self-regulated learning aspect. The students are learning for about 4 months mathematics using self-regulated learning method. Materials taken for the treatment process in students using Textbooks and interactive learning media software. Textbooks prepared covering material Triangle Quadrilateral, Linear Equations and Inequalities One Variable, Arithmetic, Social Transformation, Probability and Statistics [5]. After completing the learning mathematics, then done the assessment of math exams.

The total number of respondents is 147 students. It consists of 70 male and 77 female. Respondent's data of research result are presented in Table 1 respondent's characteristic. The table illustrates the distribution of respondents grouped into gender and internet usage intensity for the following school categories. The intensity of internet use is very frequent in regular schools.

Table 1. Respondent's characteristic

\begin{tabular}{lccc}
\hline \multicolumn{1}{c}{ Characteristic } & Excellent Schools (ES) & Regular School (RS) & Total \\
\hline Gender & & & \\
- Male & 33 & 37 & 70 \\
- Female & 39 & 38 & 77 \\
Intensity of Internet use: & & & \\
a. Very rare & 5 & 1 & 6 \\
b. Rarely & 10 & 6 & 16 \\
c. Sometimes & 11 & 17 & 28 \\
d. Often & 24 & 25 & 49 \\
e. Very Often & 22 & 26 & 48 \\
\hline
\end{tabular}

\subsection{Designing and Creating Questionnaires}

The questionnaire designed and constructed is divided into three sections. The demographics of the respondents were filled in at the beginning of the questionnaire. The content section of the Questionnaire contains questions about the use of the internet (playing games, social media, or both) and other information related to the research. The third part of the questionnaire contains the measurements of each aspect of selfregulated learning. Aspects of self-regulated learning value formers amount to 10 aspects [7] and each aspect is generated from statements filled by respondents.

\subsection{Secondary Data Retrieval}

Secondary data taken from the data of this research is the value of mathematics test from respondent. After the previous respondents, follow the method of self-regulated learning for math lessons for four months. The value obtained from the teacher of mathematics teacher.

\subsection{Analysis of Research Data}

The results of research data can see in Table 2. Research data with different gender and school's category. The table shows the use of the internet (for games, social media or both). School categories (excellent and regular schools) and based on gender differences. The table also shows the intensity of internet usage, the average value of mathematics exam and the average combined value of self-regulated learning. Internet use to play games in male is more dominant, compared with female. While the use of social media tend to be more widely used by female.

The intensity of internet usage by respondents tends to be frequent in a day, although the tendency in male is very frequent using internet connection. Comparison between two different schools for the average score of mathematics exams found that, male values tend to be higher than female, in both categories of schools are. 
Table 2. Research data with different gender and school's category

\begin{tabular}{|c|c|c|c|c|c|c|c|}
\hline \multirow[b]{2}{*}{ No. } & \multirow[b]{2}{*}{ Variable } & \multicolumn{3}{|c|}{ Male } & \multicolumn{3}{|c|}{ Female } \\
\hline & & $\begin{array}{c}\text { Excellent } \\
\text { Schools (ES) }\end{array}$ & $\begin{array}{c}\text { Regular } \\
\text { School (RS) }\end{array}$ & Total & $\begin{array}{c}\text { Excellent } \\
\text { Schools (ES) }\end{array}$ & $\begin{array}{c}\text { Regular } \\
\text { School (RS) }\end{array}$ & Total \\
\hline \multirow{3}{*}{1} & $\begin{array}{l}\text { Use of the Internet for: } \\
\text { a. Game }\end{array}$ & 26 & 19 & 45 & 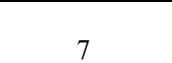 & 8 & 15 \\
\hline & b. Social Media & 5 & 10 & 15 & 20 & 15 & 35 \\
\hline & c. Both of them & 2 & 8 & 10 & 12 & 15 & 27 \\
\hline \multirow{6}{*}{2} & Intensity of use Internet & & & & & & \\
\hline & a. Very rare & 3 & 0 & 3 & 2 & 1 & 3 \\
\hline & b. Rarely & 4 & 3 & 7 & 6 & 3 & 9 \\
\hline & c. Sometimes & 6 & 8 & 14 & 5 & 9 & 14 \\
\hline & d. Often & 9 & 12 & 21 & 15 & 13 & 28 \\
\hline & e. Very Often & 11 & 14 & 25 & 11 & 12 & 23 \\
\hline 3 & $\begin{array}{l}\text { Average the value of a } \\
\text { math exam }\end{array}$ & $87.9 \%$ & $68.1 \%$ & $\begin{array}{c}78.0 \\
\%\end{array}$ & $86.8 \%$ & $64.7 \%$ & $\begin{array}{c}75.8 \\
\%\end{array}$ \\
\hline 4 & $\begin{array}{l}\text { Average self-regulated } \\
\text { learning }\end{array}$ & $62.4 \%$ & $59.8 \%$ & $\begin{array}{c}61.1 \\
\%\end{array}$ & $86.7 \%$ & $65.3 \%$ & $\begin{array}{l}76.0 \\
\%\end{array}$ \\
\hline
\end{tabular}

Table 2 shows for the average test scores in general both female and male tend to be larger in excellent schools. The value of student learning independence obtained the highest score in female compared to male for the average of all aspects. This should have reviewed by examining the details of the Table 3 and 4.

Table 3. Self-regulated learning results of each aspect

\begin{tabular}{|c|c|c|c|c|c|c|c|c|}
\hline \multirow{2}{*}{\multicolumn{2}{|c|}{ Aspect of Self-Regulated Learning }} & \multicolumn{3}{|c|}{ Male } & \multicolumn{3}{|c|}{ Female } & \multirow{2}{*}{$\begin{array}{l}\text { AVR Total } \\
\text { for each } \\
\text { aspect }(\%)\end{array}$} \\
\hline & & ES & RS & AVR & ES & RS & AVR & \\
\hline $\mathrm{A}$ & Learning Initiative & 52.65 & 54.32 & 53.54 & 49.42 & 51.32 & 50.36 & 51.93 \\
\hline $\mathrm{B}$ & Diagnosing the Needs of Learning & 67.32 & 4.00 & 63.98 & 63.74 & 65.32 & 64.52 & 50.09 \\
\hline $\mathrm{C}$ & Setting Learning Objectives & 57.58 & 56.25 & 56.88 & 55.29 & 58.06 & 56.66 & 56.79 \\
\hline $\mathrm{D}$ & Organize and Control Performance or Learning & 64.47 & 59.32 & 61.75 & 63.14 & 60.59 & 61.88 & 61.88 \\
\hline $\mathrm{E}$ & $\begin{array}{l}\text { Organize and Control Cognition, Motivation, } \\
\text { Behavior (Self) }\end{array}$ & 57.71 & 57.68 & 57.69 & 55.07 & 58.19 & 56.61 & 57.16 \\
\hline $\mathrm{F}$ & Viewing Difficulties as a Challenge & 61.36 & 56.53 & 58.81 & 62.61 & 58.44 & 60.55 & 59.74 \\
\hline G & Finding and Utilizing Relevant Learning Resources & 59.31 & 56.95 & 58.06 & 54.95 & 56.02 & 55.47 & 56.80 \\
\hline $\mathrm{H}$ & Choosing and Applying Learning Strategies & 68.01 & 69.52 & 68.81 & 68.52 & 69.88 & 69.19 & 68.98 \\
\hline I & Evaluating Learning Processes and Results & 74.03 & 72.59 & 73.27 & 71.98 & 67.29 & 69.67 & 71.47 \\
\hline $\mathrm{J}$ & Self-efficacy (Self Concept) & 61.26 & 54.25 & 57.55 & 60.53 & 59.30 & 59.93 & 58.83 \\
\hline
\end{tabular}

Table 3 shows generally the total value of self-regulated learning. In Table 3, the assessment of each aspect of the self-regulated learning assessed. Based on the results of the table can be seen on average aspects of Evaluating Learning Processes and Results is the most dominant aspect of forming the value of independence. These results cannot show how the main component of self-regulated learning is dominant for each gender and school category, so it is necessary to sort the highest value of 10 components of selfregulated learning formation. The table presented in Table 4 below.

Table 4. Sequence of priority aspect self-regulated learning on gender and school type

\begin{tabular}{|c|c|c|c|c|c|c|c|c|c|c|c|}
\hline \multirow{2}{*}{ No } & \multirow{2}{*}{ Category Gender and Type of Schools } & \multicolumn{10}{|c|}{ Priority Self-Regulated Learning (Based on Aspect SRL) } \\
\hline & & 1 & 2 & 3 & 4 & 5 & 6 & 7 & 8 & 9 & 10 \\
\hline \multirow{4}{*}{1} & Male & & & & & & & & & & \\
\hline & a. Excellent schools & I & $\mathrm{H}$ & B & $\mathrm{D}$ & $\mathrm{F}$ & $\mathrm{J}$ & G & $\mathrm{E}$ & $\mathrm{C}$ & A \\
\hline & b. Regular School & I & $\mathrm{H}$ & B & $\mathrm{D}$ & $\mathrm{E}$ & G & $\mathrm{F}$ & $\mathrm{C}$ & A & $\mathrm{J}$ \\
\hline & $\begin{array}{l}\text { c. Average for both } \\
\text { Female }\end{array}$ & I & $\mathrm{H}$ & B & $\mathrm{D}$ & $\mathrm{F}$ & G & $\mathrm{E}$ & $\mathrm{J}$ & $\mathrm{C}$ & A \\
\hline \multirow{4}{*}{2} & a. Excellent schools & I & $\mathrm{H}$ & B & $\mathrm{D}$ & $\mathrm{F}$ & $\mathrm{J}$ & $\mathrm{C}$ & $\mathrm{E}$ & G & A \\
\hline & b. Regular School & $\mathrm{H}$ & I & B & $\mathrm{D}$ & $\mathrm{J}$ & $\mathrm{F}$ & $\mathrm{E}$ & $\mathrm{C}$ & G & A \\
\hline & c. Average for both & I & $\mathrm{H}$ & B & $\mathrm{D}$ & $\mathrm{F}$ & $\mathrm{J}$ & $\mathrm{C}$ & $\mathrm{E}$ & G & A \\
\hline & Total SRL for all Gender & I & $\mathrm{H}$ & B & $\mathrm{D}$ & $\mathrm{F}$ & $\mathrm{J}$ & $\mathrm{E}$ & $\mathrm{C}$ & G & A \\
\hline
\end{tabular}

Table 4 shows the greatest priority sequence of self-regulated learning-forming aspects, the overall greatest sequence of self-regulated learning total scores are I (Evaluating Learning Processes and Results), Aspects H (Choosing and Applying Learning Strategies), B (Diagnosing the Needs of Learning) and so on. The difference between male and female on the order of priority of self-regulated learning value-formers is

APTIKOM J. CSIT Vol. 4, No. 2, 2019 : $69-73$ 
in the 6th order, for the $\mathrm{G}$ (Finding and Utilizing Relevant Learning Resources) aspect is more dominant for men, whereas in order of priority tend to aspect $\mathrm{J}$ (Self- efficacy (Self Concept)) is dominant, in affecting the value of self-regulated learning total.

Table 5. Summary of research results

\begin{tabular}{|c|c|c|c|c|c|}
\hline No & $\begin{array}{l}\text { Category Gender and } \\
\text { Type of Schools }\end{array}$ & $\begin{array}{l}\text { Self-Regulated Learning } \\
\text { Dominant Aspect }\end{array}$ & SRL Total & $\begin{array}{l}\text { The value of } \\
\text { the math test }\end{array}$ & $\begin{array}{l}\text { Priority } \\
\text { Internet usage }\end{array}$ \\
\hline & Male & & & & \\
\hline 1 & $\begin{array}{l}\text { Average for excellent } \\
\text { and regular schools }\end{array}$ & $\begin{array}{l}\text { Aspect G (Finding and Utilizing Relevant } \\
\text { Learning Resources) Priority level } 6 \text { SRL }\end{array}$ & 61.1 & 78.0 & Play Game \\
\hline & Female & & & & \\
\hline 2 & $\begin{array}{l}\text { Average for excellent } \\
\text { and regular schools }\end{array}$ & $\begin{array}{l}\text { Aspect J (Evaluating Learning Processes } \\
\text { and Results) Priority level } 6 \text { SRL }\end{array}$ & 76.0 & 75.8 & Social Media \\
\hline
\end{tabular}

Based on the description of the previous discussion then Table 5 is a summary of this study. Table 5 shows that in male and female are different for the dominant aspect of forming the value of learning independence is for male tend to aspect $\mathrm{G}$ of Finding and Utilizing Relevant Learning Resources and for female in aspect of J Evaluating Learning Processes and Results. It presumed that the mathematics lessons presented in the treatment process are resembled games, and the majority of male have more dominant game play habits, so it is natural that the mathematical value is greater, and the $\mathrm{G}$ aspect is more dominant for this case. In contrast to the total value of self-regulated learning, female are more dominant and adaptable to self-learning, as reflected in the average total value of female self-regulated learning greater than male self-regulated learning. The tendency of female to use social media is supportive aspects of $\mathbf{J}$ Evaluating Learning Processes and Results.

\section{Conclusion}

The use of internet for games and social media can influence aspects of self-regulated learning assessment. In dominant male using internet for games tend to have $G$ aspect of Finding and Utilizing Relevant Learning Resources on greater self-regulated learning assessment, another case with dominant female using social media tend to have aspects of J Evaluating Learning Processes and Results . This applies to this case and to mathematics lessons. Further research needs to be done, especially research related to the aspects of self-regulated learning for different subjects, eg language and social sciences. The use of the internet can be developed for students so that the formation of self-regulated learning can be seen.

\section{References}

[1] Ruzgar, N. A Research on The Purpose of Internet Usage and Learning via Internet. The Turkish Online Journal of Educational Technology. 2005; 4(4): 27-32.

[2] APJII, Asosiasi penyelenggara jasa internet Indonesia. Report number Edisi 05 November 2016. available on: https://apjii.or.id/downfile/file/BULETINAPJIIEDISI05November2016.pdf

[3] Stanciua V, Tincaa A. A critical look on the student's Internet use - an empirical study, Accounting and Management Information Systems. 2014; 13(4): 739-754.

[4] Tshering, K. To Study the Internet Access and Usage Behavior in the Kingdom of Bhutan. International Journal of Computer Science and Electronics Engineering (IJCSEE). 2013; 1(2): 27-32. ISSN 2320-4028 available on: http://www.isaet.org/images/extraimages/P413160.pdf

[5] Nani Ratnaningsih, Edi Hidayat, and R. Reza El Akbar. Scientific Approach-Based of Interactive Learning Media to Improve Mathematical Thinking Skill and Self-Regulated Learning. Proceedings of the 2nd SULE - IC 2016, FKIP, Unsri, Palembang. 2016;759-768.

[6] Magno C. Developing and Assessing Self-Regulated Learning. The Assessment Handbook: Continuing Education Program, vol. 1, May 2009.

[7] Sumarmo, U. Independence Learning: What, Why, and How Developed in Students (in Bahasa). Makalah Disajikan pada Seminar Pendidikan Matematika di Jurusan Pendidikan Matematika FMIPA Universitas Yogyakarta, Jul 8, 2004.

[8] Nani Ratnaningsih, Edi Hidayat, and R. Reza El Akbar. Interactive Learning Media Based on Scientific Approaches in Developing Mathematical Thinking Abilities and Self Regulated Learning in Middle School Students (in Bahasa). Laporan Kemajuan Hibah Prodsuk Terapan. Universitas Siliwangi. 2017. 